\title{
Drip-irrigated Pecan Seedlings Response to Irrigation Water Salinity
}

\author{
Sanjit K. Deb ${ }^{1}$, Parmodh Sharma, Manoj K. Shukla, \\ and Theodore W. Sammis \\ Department of Plant and Environmental Sciences, New Mexico State \\ University, MSC 3Q, P.O. Box 30003, Las Cruces, NM 88003
}

\author{
Jamshid Ashigh \\ Department of Extension Plant Sciences, New Mexico State University, MSC \\ 3AE, P.O. Box 30003, Las Cruces, NM 88003
}

Additional index words. Carya illinoinensis, bud break, electrical conductivity, leachate, potin-pot, salt stress, seedling growth

\begin{abstract}
Salinity responses and salinity-related suppression of budbreak of dripirrigated pecan [Carya illinoinensis (Wangenh.) K. Koch] seedlings under different irrigation water salinity $\left(\mathrm{EC}_{\mathrm{IRR}}\right)$ levels were investigated in the pot-in-pot system. The 1-year-old pecan seedlings of rootstock 'Riverside' grafted with 'Western Schley' scions were transplanted in pots filled with sandy loam soil and grown for 2 years under the same amount of irrigation water but four irrigation $\mathrm{EC}_{\mathrm{IRR}}$ treatment levels consisting of $1.4 \mathrm{dS} \cdot \mathrm{m}^{-1}$ (control), and three qualities of irrigation water obtained by using a solution of calcium chloride $\left(\mathrm{CaCl}_{2}\right)$ and sodium chloride $(\mathrm{NaCl})$ in a ratio of $2: 1$ (by weight) to reach the $\mathrm{EC}_{\mathrm{IRR}}$ levels of $3.5,5.5$, and $7.5 \mathrm{dS} \cdot \mathrm{m}^{-1}$, respectively. The leachate electrical conductivity $\left(E C_{d}\right)$ was highly correlated with soil salinity $\left(E C_{1: 1}\right)$ and was significantly higher when the irrigation $\mathrm{EC}_{\mathrm{IRR}}$ treatment levels increased from 1.4 (control) to $7.5 \mathrm{dS} \cdot \mathrm{m}^{-1}$. However, both $\mathrm{EC}_{\mathrm{d}}$ and $\mathrm{EC}_{1: 1}$ remained nearly constant within the same irrigation $\mathrm{EC}_{\mathrm{IRR}}$ treatment level during both years. Increasing salinity in irrigation water, particularly the $\mathrm{EC}_{\text {IRR }}$ levels of 5.5 and $7.5 \mathrm{dS} \cdot \mathrm{m}^{-1}$, showed significantly low seedling height and stem diameter growth and delayed or even inhibited budbreak in the seedlings. The $\mathrm{EC}_{1: 1}$ that inhibited seedling heights, stem diameters, and budbreak was somewhere between 0.89 and $2.71 \mathrm{dS} \cdot \mathrm{m}^{-1}$ (or $\mathrm{EC}_{\text {IRR }}$ between 1.4 and $3.5 \mathrm{dS} \cdot \mathrm{m}^{-1}$ and $\mathrm{EC}_{\mathrm{d}}$ between 2.10 and $4.86 \mathrm{dS} \cdot \mathrm{m}^{-1}$ ), providing that soil water content was not a limiting factor in the root zone and irrigation water was uniformly distributed in the confined root zone to obtain uniform salt leaching. The visual symptoms of leaf scorch for irrigation $\mathrm{EC}_{\text {IRR }}$ levels of $3.5,5.5$, and $7.5 \mathrm{dS} \cdot \mathrm{m}^{-1}$ also indicated that somewhere between 0.89 and 2.71 $\mathrm{dS} \cdot \mathrm{m}^{-1}$ of the $\mathbf{E C}_{1: 1}$, salt injury started to occur. Increasing salinity in irrigation water significantly increased chloride $\left(\mathrm{Cl}^{-}\right)$accumulation but reduced nitrogen $(\mathrm{N})$ content in the scorched leaves, particularly under the irrigation $\mathrm{EC}_{\text {IRR }}$ levels of 5.5 and $7.5 \mathrm{dS} \cdot \mathrm{m}^{-1}$. Leaf scorch symptoms in pecan seedlings were likely associated with $\mathrm{Cl}^{-}$toxicity. No pecan seedlings under the irrigation $\mathrm{EC}_{\mathrm{IRR}}$ treatment levels of 5.5 and $7.5 \mathrm{dS} \cdot \mathrm{m}^{-1}$ survived to the end of the 2-year growing period. Thus, threshold $\mathrm{EC}_{1: 1}$ was somewhere between 0.89 and $2.71 \mathrm{dS} \cdot \mathrm{m}^{-1}$ beyond which plant injury increases with increasing $\mathrm{EC}_{1: 1}$ threatening the survival of pecan seedlings.
\end{abstract}

Salinity stress is an ever-present environmental constraint to crop productivity in arid and semiarid regions. The quality of irrigation water remains a primary factor influencing soil salinity. In the arid and semiarid

\footnotetext{
Received for publication 17 July 2013. Accepted for publication 29 Oct. 2013

We thank the New Mexico State University Agricultural Experiment Station for support and the Specialty Crop Research Initiative (SCRI), USDA-CSREES, for funding this research; Dr. Rolston St. Hilaire, Department of Plant and Environmental Sciences, New Mexico State University, for providing us with the pot-in-pot units; and Dr. John G. Mexal and Dr. Blair L. Stringam, Department of Plant and Environmental Sciences, New Mexico State University, Las Cruces, NM, for their helpful suggestions on an earlier draft of the manuscript.

${ }^{1}$ To whom reprint requests should be addressed; e-mailsanjit@nmsu.edu.
}

southwestern United States, the occurrence of salt-affected soils in pecan orchards is common in upland soils irrigated with moderately saline water $\left(1\right.$ to $\left.2 \mathrm{dS} \cdot \mathrm{m}^{-1}\right)$ and in alluvial soils with poor drainage or inadequate permeability (Miyamoto and Storey, 1995). High evapotranspiration rates exceeding rainfall as well as poor-quality irrigation water containing considerable amounts of salts have accentuated salt problems across pecan-producing areas of this region. Salts present in the soil and irrigation water are expected to increase as the competition for freshwater uses among domestic, agriculture, and industrial sectors intensifies; the expectation of optimized consumptive water use of pecans and enhanced irrigation efficiency grows; and the increased emphasis on conservation of water resources in conflict with the necessity of large amounts of good-quality irrigation water for pecan production continues.
Irrigation water in pecan-producing areas of the southwestern United States, a leading pecan-producing region in the nation, is considerably saline and less sodic (Miyamoto and Storey, 1995). The supply of good-quality water from river irrigation projects has become increasingly limited in many areas. The shortfall is commonly supplemented with groundwater that may have elevated salinity. Most irrigation water from groundwater sources in the pecan-producing areas of the southwestern region contains 500 to $1500 \mathrm{ppm}$ of dissolved salts, resulting in 5 to 15 tons of salts per hectare carried into the orchard annually (Miyamoto et al., 1995). Picchioni et al. (2000) surveyed 15 commercial pecan orchards along a $120-\mathrm{km}$ stretch of the middle Rio Grande basin in southern New Mexico to evaluate whether pecan cultivation in this region was threatened by high soil salinity. Ten of the 15 sites were found to be on soils considered too saline for pecan trees with the soil saturated paste electrical conductivity (EC) values between 2 and $3 \mathrm{dS} \cdot \mathrm{m}^{-1}$ at the upper 0 to $60 \mathrm{~cm}$ of soil depth. Water availability is considered one of the major constraints to pecan productivity in the southwestern United States (Deb et al., 2011, 2013), but the decline in irrigation water quality, particularly salinity, continues to be a major challenge to pecan production in this region.

Pecans are among the most salt-sensitive tree crops, yet there is a paucity of research concerning the effects of soil and irrigation water salinity on the growth of pecans. Miyamoto and Gobran (1983) reported that symptoms of salt damage to mature pecan trees ranged from marginal leaf tip burn to mortality of trees. The threshold soil salinity of the saturation extract in the main root zone for tree growth appears to be $\approx 2.0 \mathrm{dS} \cdot \mathrm{m}^{-1}$ when sodium $\left(\mathrm{Na}^{+}\right)$ is the dominant cation (Miyamoto et al., 1986; Miyamoto and Nesbitt, 2011). Tree growth decreases when soil salinity of the saturation extract reaches 2 to $3 \mathrm{dS} \cdot \mathrm{m}^{-1}$ and ceases at soil salinity of 4 to $5 \mathrm{dS} \cdot \mathrm{m}^{-1}$, and branch dieback begins at soil salinity of $\approx 5$ to $6 \mathrm{dS} \cdot \mathrm{m}^{-1}$ in the soil saturation extract (Miyamoto et al., 1986; Miyamoto and Nesbitt, 2011). High soil salinity also causes reduction in nut size and yield (Miyamoto et al., 1986).

The responses of pecans to high salinity may be expected to vary with growth stage. There have been only a few studies that have examined the responses of pecan seedlings to irrigation water salinity levels. In particular, it is difficult to assess the effects of increased salinity of irrigation water or quality of irrigation water on budbreak or growth of pecan seedlings. In a greenhouse experiment where healthy seedlings were subjected to short-term exposure to saline solutions, Faruque (1968) reported that leaf injury of pecan seedlings (cv. Riverside) was related to chloride $\left(\mathrm{Cl}^{-}\right)$ but not $\mathrm{Na}^{+}$or $\mathrm{SO}_{4}{ }^{2-}$ ions. Miyamoto et al. (1985) studied the effects of $\mathrm{Na}^{+}$and $\mathrm{Cl}^{-}$on growth and ion uptake of three rootstock cultivars, Apache, Burkett, and Riverside, which were grown in outdoor lysimeters and irrigated with eight different qualities. Seedling growth, evaluated in terms of leaf, stem, 
and root weights, was inversely related to $\mathrm{Na}^{+}$concentrations in both soil solutions and seedling leaves. Because the Riverside cultivar absorbed substantially lesser $\mathrm{Na}^{+}$, Miyamoto et al. (1985) recommended that 'Riverside' was a better suited rootstock for saline areas. However, no studies have examined whether increased salinity of irrigation water suppresses budbreak of grafted seedlings or whether salt-affected buds adjust to salt stress under higher irrigation water salinity treatment levels. The objective of this study was to compare salinity responses and salinity-related suppression of budbreak of drip-irrigated pecan seedlings of rootstock 'Riverside' grafted with 'Western Schley' scions under different irrigation water salinity treatment levels.

\section{Materials and Methods}

An in-ground, pot-in-pot experiment was conducted from Feb. 2009 to Oct. 2010 at New Mexico State University's Fabian Garcia Science Center (FGSC) in Las Cruces, NM (lat. $32^{\circ} 16^{\prime} 51.76^{\prime \prime} \mathrm{N}$, long. $106^{\circ} 46^{\prime} 30.76^{\prime \prime} \mathrm{N}$; elevation $1186 \mathrm{~m}$ ). The 34-L (upper external diameter $=36 \mathrm{~cm}$; height $=36 \mathrm{~cm})$ plastic holder or socket pots (Eco-Lip/Econo-Grip GL/EG 4000; Nursery Supplies, Orange, CA) were placed in the ground with the top rim remaining above ground level. The cultivation pots (hereafter referred to as the pot) containing pecan seedlings were then placed within the holder pots. In this study, we used a total of 24 holder pots. Holder pots were placed in four rows $65 \mathrm{~cm}$ apart, and each treatment row had six pots. The area within and between rows was bare sandy loam soil.

Each pot contained small drainage holes at the bottom and a plastic permeable mulch cover was placed on the base of pot. This allowed for drainage within the holder pot and thus collection of leachate. Each pot was filled with sandy loam soil. The soil particle size distribution was determined (sand $63.60 \% \pm$ $0.86 \%$, silt $27.50 \% \pm 0.96 \%$, and clay $8.90 \% \pm$ $0.10 \%$ ) using the hydrometer method (Gee and Bauder, 1986). Other physical properties of the sandy loam soil including soil bulk density (ranged from $1.37 \pm 0.04$ to $1.44 \pm$ $0.02 \mathrm{Mg} \cdot \mathrm{m}^{-3}$ ), saturated hydraulic conductivity (ranged from $17.3 \pm 1.44$ to $92.2 \pm 4.46$ $\mathrm{cm} \cdot \mathrm{d}^{-1}$ ), field capacity water content at $30 \mathrm{kPa}$ (ranged from $0.17 \pm 0.03$ to $0.27 \pm$ $\left.0.0 \mathrm{~cm}^{3} \cdot \mathrm{cm}^{-3}\right)$, and wilting point water content at $1500 \mathrm{kPa}\left(0.10 \pm 0.04 \mathrm{~cm}^{3} \cdot \mathrm{cm}^{-3}\right)$ were reported in Deb et al. $(2011,2013)$.

Pecan seedlings, one seedling per pot, were transplanted on 25 Feb. 2009. One-year-old seedlings of rootstock 'Riverside' grafted with 'Western Schley' scions were selected from a local nursery (Peñas Pecan Nursery, Mesilla Park, NM). Before transplantation, roots of all the seedlings were trimmed to 30.5 -cm length. A drip irrigation system was installed to irrigate the seedlings at a rate of $3.8 \mathrm{~L} \cdot \mathrm{h}^{-1}$. The drip irrigation system consisted of one drip tubing supply line at each pot-in-pot row, one drip emitter per pot to distribute water over the surface of the pot to develop a uniform root system in the pot, and a series of four water storage tanks to apply groundwater and saline irrigation. All the pots were irrigated to saturation with groundwater $\left(\mathrm{EC}_{\mathrm{IRR}}=\right.$ $1.4 \mathrm{dS} \cdot \mathrm{m}^{-1}$ ) before being subjected to irrigation water salinity $\left(\mathrm{EC}_{\mathrm{IRR}}\right)$ level treatments from Mar. 2009 to Oct. 2010. Four irrigation water salinity $\left(\mathrm{EC}_{\mathrm{IRR}}\right)$ treatment levels were applied to the pecan seedlings: irrigation with groundwater $\left(\mathrm{EC}_{\mathrm{IRR}}=1.4 \mathrm{dS} \cdot \mathrm{m}^{-1}\right)$ available in the FGSC (considered as a control) and three higher salinity treatment levels $\left(\mathrm{EC}_{\mathrm{IRR}}=\right.$ 3.5, 5.5, and $7.5 \mathrm{dS} \cdot \mathrm{m}^{-1}$ ). Concentrations of $\mathrm{Na}^{+}, \mathrm{Ca}^{2+}, \mathrm{Mg}^{2+}, \mathrm{K}^{+}, \mathrm{NO}_{3}-\mathrm{N}$, and $\mathrm{Cl}^{-}$in the control irrigation water were $56.6 \pm 0.5,75.3 \pm$ $0.7,12.8 \pm 0.2,5.0 \pm 0.2,0.05 \pm 0.02$, and $70.0 \pm 1.95 \mathrm{mg} \cdot \mathrm{L}^{-1}$, respectively. Each of the three $\mathrm{EC}_{\mathrm{IRR}}$ treatment levels $(3.5,5.5$, and $7.5 \mathrm{dS} \cdot \mathrm{m}^{-1}$, respectively) was obtained by gradually adding amounts of calcium chloride $\left(\mathrm{CaCl}_{2}\right)$ and sodium chloride $(\mathrm{NaCl})$ in a ratio of 2:1 (by weight) to the irrigation solution and by determining the incremental EC of the solution with a portable EC meter (ECtestr 11; Oakton Instruments, Vernon Hills, IL) until it reached the desired level of $\mathrm{EC}_{\mathrm{IRR}}$. Treatments were replicated six times with one pecan seedling per replication.

Interactive effects of salinity and water stress were not considered in this study, and therefore, pecan seedlings under all treatments were well watered to prevent soil water stress. The amount of water added to each pot was adjusted every 1 to 2 weeks according to the average amount of gravimetric moisture loss (e.g., Catlin et al., 1993; St. Hilaire et al., 2003). Pots were weighed on a batteryoperated, portable top-loading balance with a capacity of $60 \mathrm{~kg} \pm 1 \mathrm{~g}$ (Model QC 60FEGSOUR; Sartorius Corp., Edgewood, NY). All the pecan seedlings were irrigated two to three times each week except for 3 months (Dec. 2009 to Feb. 2010) when irrigation was applied once a week. The amount of water per irrigation added to each pot was $1.5 \mathrm{~L}$ during the period from Mar. to Apr. 2009 and $2.5 \mathrm{~L}$ from May 2009 to Oct. 2010. The irrigation was applied in the morning (between $0800 \mathrm{HR}$ and $1000 \mathrm{HR}$ ).

Two watermark sensors (Irrometer Company, Inc., Riverside, CA) were installed at 7and $15-\mathrm{cm}$ depths in each of the two pots under the irrigation $\mathrm{EC}_{\mathrm{IRR}}$ treatment levels of 3.5 and $5.5 \mathrm{dS} \cdot \mathrm{m}^{-1}$, respectively. Watermark sensors were connected to Hobo $\mathrm{H} 8$ data loggers (Onset Computer Corporation, Bourne, MA), which recorded voltage signals every $30 \mathrm{~min}$. Following the procedure described by Allen (1999), a 10-k $\Omega, 1 / 4-\mathrm{W}, 0.1 \%$ tolerance metal film resistor was added to the input cable lead from the watermark sensor to reduce the amount of voltage drop across the sensor, minimize data logger battery drainage, and consequently the resolution of the measurement.

The effect of salinity on watermark sensors was not considered for the $3.5-\mathrm{dS} \cdot \mathrm{m}^{-1}$ and $5.5-\mathrm{dS} \cdot \mathrm{m}^{-1}$ treatment pots where a large amount of irrigation water was frequently applied to leach salts from the soil profile. Scanlon and Andraski (2002) suggested that salinity errors may be reduced for gypsumbased electrical resistance sensors because of the buffering capacity of the ions provided during dissolution of the gypsum. For the similar reason, the internal gypsum tablet of the watermark sensor buffers against the salinity levels as well as the sensor's sensitivity to soil EC is minimal when the sensors are new. Varble and Chávez (2011) did not consider the error salinity (in the range of 0.88 to 5.92 $\mathrm{dS} \cdot \mathrm{m}^{-1}$ ) might introduce in the manufacturer's calibration of soil water content.

Varble and Chávez (2011) reported that the manufacturer's calibration overestimated soil water contents as compared with water content values derived from gravimetric samples from permanent wilting point to field capacity water contents. In contrast, for moist soil conditions, i.e., where soil is not drying rapidly and water content remains high, the calibration equation for watermark sensor developed by Shock et al. (1998), which is used by the manufacturer as a default calibration, is reported to provide a good estimate of soil matric potential $(\psi, \mathrm{kPa})$ (e.g., Thompson et al., 2006). Therefore, in this study, $\psi(\mathrm{kPa})$ was estimated from the voltage measured by the watermark sensors using the non-linear equation of Shock et al. (1998):

$$
\begin{aligned}
\psi= & \frac{[4.093+3.213 \times\{10 \mathrm{~V} /(2.5-V)\}]}{[1-0.009733 \times\{10 \mathrm{~V} /(2.5-V)\}]} \\
& -\left(0.01205 \times T_{s}\right)
\end{aligned}
$$

where the term $\{10 \mathrm{~V} /(2.5-\mathrm{V})\}$ is the resistance of the sensor $(\mathrm{k} \Omega), \mathrm{V}$ is the measured voltage from the sensor and recorded by the data logger (volts), and $\mathrm{T}_{\mathrm{s}}$ is the measured soil temperature $\left({ }^{\circ} \mathrm{C}\right)$ near the watermark sensor. Two pots under the irrigation $\mathrm{EC}_{\mathrm{IRR}}$ treatment levels of 3.5 and $5.5 \mathrm{dS} \cdot \mathrm{m}^{-1}$ were also instrumented with temperature sensors (TMC6-HD; Onset Computer Corp., Bourne, MA). These sensors were installed at 10 - and $20-\mathrm{cm}$ depths and connected to Hobo H8 data loggers (Onset Computer Corp.). Soil temperatures were recorded every $30 \mathrm{~min}$. The soil water retention model of van Genuchten (1980) was used to convert $\psi$ to volumetric soil water content $[\theta(\psi)]$ :

$$
\theta(\psi)= \begin{cases}\theta_{\mathrm{r}}+\frac{\left(\theta_{\mathrm{s}}-\theta_{\mathrm{r}}\right)}{\left[1+|\alpha \psi|^{\mathrm{n}}\right]^{\mathrm{m}}} & \psi<0 \\ \theta_{\mathrm{s}} & \psi \geq 0\end{cases}
$$

where $\theta_{\mathrm{r}}$ is the residual $\theta\left(\mathrm{cm}^{3} \cdot \mathrm{cm}^{-3}\right) ; \theta_{\mathrm{s}}$ is the saturated $\theta\left(\mathrm{cm}^{3} \cdot \mathrm{cm}^{-3}\right)$; and $\alpha$ (air entry parameter, $\mathrm{cm}^{-1}$ ), $\mathrm{n}$ (pore size distribution parameter, unitless), and $m(=1-1 / n)$ are empirical parameters. The soil water retention curve for sandy loam soil was determined using the pressure chamber method at $\psi$ of $0,30,50,100,300,500,1000$, and 1500 $\mathrm{kPa}$ (Deb et al., 2011). The parameters $\theta_{\mathrm{r}}$ $\left(=0.08 \mathrm{~cm}^{3} \cdot \mathrm{cm}^{-3}\right), \theta_{\mathrm{s}}\left(=0.46 \mathrm{~cm}^{3} \cdot \mathrm{cm}^{-3}\right), \alpha$ $\left(=0.003 \mathrm{~cm}^{-1}\right)$, and $\mathrm{n}(=2.0)$ were estimated by fitting the van Genuchten (1980) soil water retention model [Eq. (2)] to the measured drainage curve data (Deb et al., 2011). 
Regression analysis was used to evaluate correlations between volumetric soil water contents at $3.5-\mathrm{dS} \cdot \mathrm{m}^{-1}$ and $5.5-\mathrm{dS} \cdot \mathrm{m}^{-1}$ treatment pots for $7-$ and $15-\mathrm{cm}$ depths, respectively.

All the pecan seedlings were fertilized with Hoagland's solution (containing 0.815 g. $\mathrm{L}^{-1}$ of soluble fertilizer) on 30 Mar., 29 May, 26 June, 20 July, and 12 Aug. during 2009 and on 4 Apr., 17 May, 15 June, 21 July, and 17 Aug. during 2010. Drainage water or leachate was collected from the holder pots every week starting from May to September during both years. The volume of leachate collected from each pot was measured using a graduated cylinder. The leaching fraction, the volume of solution leached divided by the volume of solution applied to the seedling, was estimated for each pot at 2-week intervals. The leachate ECs $\left(\mathrm{EC}_{\mathrm{d}}\right)$ were measured at 2-week intervals in the field using a portable EC meter (ECtestr 11; Oakton Instruments, Vernon Hills, IL) and also in the laboratory using a Fisher Accumet Meter (Denver Instrument Company, Denver, CO).

Soil samples at depths of 0 to $20 \mathrm{~cm}$ were collected from all treatment pots using a push probe to determine soil EC on a monthly basis at the time of leachate volume sampling. Gravimetric water contents at 7- and $15-\mathrm{cm}$ depths were also determined once per month and compared with soil water contents obtained using Eq. (2) for two pots under the irrigation $\mathrm{EC}_{\mathrm{IRR}}$ treatment levels of 3.5 and $5.5 \mathrm{dS} \cdot \mathrm{m}^{-1}$. Soil samples that were removed from each pot during the sampling were replaced by the same soil type. Soil samples were air-dried, passed through a 2-mm sieve, and analyzed for the EC in 1:1 ratio of soil: water $\left(\mathrm{EC}_{1: 1}\right)$ using the Fisher Accumet Meter (Denver Instrument Company). Although the saturated paste extract method is generally accepted, we determined soil EC $\left(\mathrm{EC}_{1: 1}\right)$ by the 1:1 soil:water method on all soil samples because of reduced time investments. Simplicity makes 1:1 soil to water extract a method potentially useful in salinity characterization
(Zhang et al., 2005). As a result of the consistency in the amount of water used, the 1:1 soil:water method reduces the difficulties in sample preparation and increases reproducibility, which are often encountered with the saturation paste extractions (e.g., Fowler and Hamm, 1980; Sonneveld and Van Den Ende, 1971; Zhang et al., 2005). Moreover, in this study, the 1:1 soil:water method was likely to be appropriate because the soil water content always remained high in all the treatment pots throughout the growing season (described in "Results and Discussion" section). Below $10-\mathrm{cm}$ depth, soil water content remained slightly below saturation but always above field capacity. The EC of sandy loam soil used in this pot-in-pot experiment was also determined on soil samples using the saturated paste extract method and in 1:1, 1:2, 1:3, 1:4, $1: 5$, and 1:10 soil:water methods to obtain the empirical relationship between soil EC levels determined using the saturated paste extract and soil to water extract methods.

The growth of seedlings in all treatment pots were monitored visually on a weekly basis as well as continuously using garden watch cameras (PlantCam; Wingscapes, Inc., Alabaster, AL). To determine annual changes in seedling height and stem diameter growth during each year, measurements of seedling heights and stem diameters were made on 2 Mar. and 5 Oct. during 2009 and 22 Mar. and 9 Oct. during 2010. Seedling height from the top of the pot to the top of the canopy was measured with a ruler. Stem diameter below the graft union was measured at $2 \mathrm{~cm}$ above the soil surface of the pot using a digital caliper. Leaf evaluations were recorded weekly starting from April to October during each year. Visual quality rating scales for evaluating salt damage on the leaves have been widely used to assess the plants (e.g., Niu et al., 2007a, 2007b; Worley, 1990; Zollinger et al., 2007). Salt damages on seedling leaves on the entire seedling were evaluated visually on a scale of 0 to 5 , where $0=$ no scorching or no visual damage; $1=$ insignificant scorching; $2=25 \%$ of leaf area scorched; $3=50 \%$ of leaf area scorched; $4=75 \%$ of leaf area scorched; and $5=$ all the leaf area scorched or dead leaf.

Weather conditions including solar radiation, minimum and maximum relative humidity, wind velocity, and minimum and maximum air temperature were measured continuously at 1-h intervals in the FGSC meteorological station. During March to October of the each year, leaf temperatures were measured once per month using an infrared thermometer (Fluke thermometer 54II; Fluke Corporation, Everett, WA). Leaves from all the treatment pots were harvested on 5 Oct. in 2009 and 9 Oct. in 2010. Leaf samples from each treatment were dried at $60{ }^{\circ} \mathrm{C}$ for $24 \mathrm{~h}$. Dried samples were then ground and sieved with a 2-mm mesh screen and analyzed for total $\mathrm{N}$ and chloride $\left(\mathrm{Cl}^{-}\right)$ contents in the AgSource Harris Laboratory (Lincoln, NE).

Data obtained from measurements were analyzed for variance using SAS for Windows Version 9.2 (SAS Institute Inc., Cary, NC). All comparisons among the four treatment means were carried out using Tukey's test ( $P \leq$ $0.05)$.

\section{Results and Discussion}

The EC of the leachate $\left(\mathrm{EC}_{\mathrm{d}}\right)$ collected from each holder pot under the irrigation water salinity $\left(\mathrm{EC}_{\mathrm{IRR}}\right)$ treatment levels of 1.4 (control), 3.5, 5.5 and $7.5 \mathrm{dS} \cdot \mathrm{m}^{-1}$ are presented in Tables 1 and 2 for 2009 and 2010, respectively. The effect of salinity level treatments was significant on the $\mathrm{EC}_{\mathrm{d}}$. The leachate samples had significantly higher $\mathrm{EC}_{\mathrm{d}}$ when the irrigation $\mathrm{EC}_{\mathrm{IRR}}$ treatment levels increased from 1.4 (control) to $7.5 \mathrm{dS} \cdot \mathrm{m}^{-1}$. The $\mathrm{EC}_{\mathrm{d}}$ within the same irrigation $\mathrm{EC}_{\mathrm{IRR}}$ treatment level remained nearly constant during both years (Tables 1 and 2). The leachate volumes within the same irrigation $\mathrm{EC}_{\mathrm{IRR}}$ treatment level remained similar at each sampling date during both years. The leachate volumes within the 2-week period usually ranged from

Table 1. Evolution of the leachate electrical conductivity $\left(\mathrm{EC}_{\mathrm{d}}\right)$ in the pot-in-pot system with pecan (Carya illinoinensis) seedlings of rootstock 'Riverside' grafted with 'Western Schley' scions grown under the irrigation water salinity (electrical conductivity, $\mathrm{EC}_{\mathrm{IRR}}$ ) treatment levels of 1.4 (control), 3.5, 5.5, and $7.5 \mathrm{dS} \cdot \mathrm{m}^{-1}$ during the 2009 growing season.

\begin{tabular}{|c|c|c|c|c|c|c|c|c|c|}
\hline \multirow[b]{2}{*}{$\mathrm{EC}_{\text {IRR }}\left(\mathrm{dS} \cdot \mathrm{m}^{-1}\right)$} & \multicolumn{9}{|c|}{ Leachate electrical conductivity $\left(\mathrm{EC}_{\mathrm{d}}\right)\left(\mathrm{dS} \cdot \mathrm{m}^{-1}\right)^{\mathrm{z}}$} \\
\hline & 7 May & 27 May & 11 June & 29 June & 15 July & 29 July & 13 Aug. & 7 Sept. & 29 Sept. \\
\hline 3.5 & $4.64 \mathrm{c}$ & $4.67 \mathrm{c}$ & $4.70 \mathrm{c}$ & $4.72 \mathrm{c}$ & $4.79 \mathrm{c}$ & $4.71 \mathrm{c}$ & $5.00 \mathrm{c}$ & $4.96 \mathrm{c}$ & $5.06 \mathrm{c}$ \\
\hline 5.5 & $7.29 \mathrm{~b}$ & $7.31 \mathrm{~b}$ & $7.35 \mathrm{~b}$ & $7.36 \mathrm{~b}$ & $7.44 \mathrm{~b}$ & $7.56 \mathrm{~b}$ & $7.67 \mathrm{~b}$ & $7.69 \mathrm{~b}$ & $7.83 \mathrm{~b}$ \\
\hline
\end{tabular}

${ }^{\mathrm{z}}$ Within each column the mean values followed by the same letters are not significantly different $(P \leq 0.05)$ based on Tukey's test.

Table 2. Evolution of leachate electrical conductivity $\left(\mathrm{EC}_{\mathrm{d}}\right)$ in the pot-in-pot system with pecan (Carya illinoinensis) seedlings of rootstock 'Riverside' grafted with 'Western Schley' scions grown under the irrigation water salinity (electrical conductivity, $\mathrm{EC}_{\mathrm{IRR}}$ ) treatment levels of 1.4 (control), 3.5, 5.5, and $7.5 \mathrm{dS} \cdot \mathrm{m}^{-1}$ during the 2010 growing season.

\begin{tabular}{|c|c|c|c|c|c|c|c|c|c|c|}
\hline \multirow[b]{2}{*}{$\mathrm{EC}_{\mathrm{IRR}}\left(\mathrm{dS} \cdot \mathrm{m}^{-1}\right)$} & \multicolumn{10}{|c|}{ Leachate electrical conductivity $\left(\mathrm{EC}_{\mathrm{d}}\right)\left(\mathrm{dS} \cdot \mathrm{m}^{-1}\right)^{\mathrm{z}}$} \\
\hline & 5 May & 18 May & 5 June & 22 June & 6 July & 22 July & 5 Aug. & 27 Aug. & $7 \mathrm{Sept}$. & $28 \mathrm{Sept}$ \\
\hline 3.5 & $4.65 \mathrm{c}$ & $4.69 \mathrm{c}$ & $4.81 \mathrm{c}$ & $4.81 \mathrm{c}$ & $4.90 \mathrm{c}$ & $4.92 \mathrm{c}$ & $4.96 \mathrm{c}$ & $4.90 \mathrm{c}$ & $4.98 \mathrm{c}$ & $5.04 \mathrm{c}$ \\
\hline
\end{tabular}

${ }^{\mathrm{z}}$ Within each column the mean values followed by the same letters are not significantly different $(P \leq 0.05)$ based on Tukey's test. 
6.6 to $8.1 \mathrm{~L}$ among all the treatment pots. Leaching fractions, the volume leached as a percentage of volume applied $(\approx 12.5 \mathrm{~L})$ to the pot surface area, were between 0.53 and 0.65 among all the treatment pots during the period from May to Sept. 2009 and 2010 with the greater leaching fraction occurring in high salinity treatment pots (i.e., $\mathrm{EC}_{\mathrm{IRR}}$ levels of 3.5, 5.5, and $7.5 \mathrm{dS} \cdot \mathrm{m}^{-1}$ ) (data not shown). This may have been caused by the reduced transpiration of seedlings because the same amount of water was applied to all the treatments. In contrast, leaching fractions based on the ratio of the irrigation water salinity $\left(\mathrm{EC}_{\mathrm{IRR}}\right)$ to the leachate salinity $\left(\mathrm{EC}_{\mathrm{d}}\right)$ (Tables 1 and 2 ) were relatively high, which ranged from 0.65 to 0.77 during both years. The lower leaching fractions based on the volumes leached and applied might relate in part to measurement errors in the amounts of leaching quantified, mainly because of the drainage water loss through the holder pot leaks. Several studies have also reported that the method based on the volumes applied and leached generally provided slightly less leaching than required to reach the targeted leaching fraction $(\mathrm{Ku}$ and Hershey, 1991, 1992).

Although soil water content was not measured in all the treatment pots, magnitudes and variations in soil water contents were likely to differ only slightly among treatments. For example, as shown in Fig. 1, magnitudes and variations in daily average volumetric soil water contents during 2009 were similar under the irrigation $\mathrm{EC}_{\mathrm{IRR}}$ treatment levels of 3.5 $\mathrm{dS} \cdot \mathrm{m}^{-1}$ and $5.5 \mathrm{dS} \cdot \mathrm{m}^{-1}$. The coefficients of determination $\left(R^{2}\right)$ between soil water contents at $3.5-\mathrm{dS} \cdot \mathrm{m}^{-1}$ and $5.5-\mathrm{dS} \cdot \mathrm{m}^{-1}$ treatment pots were 0.95 and $0.96(P \leq 0.05)$ for 7 - and 15-cm depths, respectively. Soil water content was not a limiting factor for different salinity treatment pots. During Mar. to Dec. 2009, measured daily average soil water contents remained higher and similar in $3.5-\mathrm{dS} \cdot \mathrm{m}^{-1}$ and $5.5-\mathrm{dS} \cdot \mathrm{m}^{-1}$ treatment pots, which varied between 0.28 and $0.40 \mathrm{~cm}^{3} \cdot \mathrm{cm}^{-3}$ at $7-\mathrm{cm}$ and 0.38 and $0.44 \mathrm{~cm}^{3} \cdot \mathrm{cm}^{-3}$ at $15-\mathrm{cm}$ soil depths with average values of 0.33 and $0.41 \mathrm{~cm}^{3} \cdot \mathrm{cm}^{-3}$

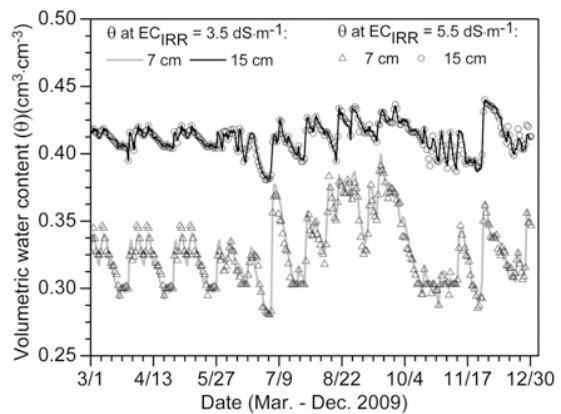

Fig. 1. Temporal variations in daily average volumetric water contents $(\theta)$ at 7 - and $15-\mathrm{cm}$ depths in the cultivation pots with pecan (Carya illinoinensis) seedlings of rootstock 'Riverside' grafted with 'Western Schley' scions grown under the irrigation water salinity (electrical conductivity, $\mathrm{EC}_{\mathrm{IRR}}$ ) treatment levels of $3.5 \mathrm{dS} \cdot \mathrm{m}^{-1}$ and $5.5 \mathrm{dS} \cdot \mathrm{m}^{-1}$ during the period from Mar. to Dec. 2009. at 7 and $15 \mathrm{~cm}$, respectively. For both 3.5 $\mathrm{dS} \cdot \mathrm{m}^{-1}$ and $5.5-\mathrm{dS} \cdot \mathrm{m}^{-1}$ treatment pots, throughout the growing season, the gradual decrease in daily soil water contents at $15-\mathrm{cm}$ depth was slower and water content remained higher compared with soil water contents at $7 \mathrm{~cm}$. The water content fluctuations between irrigation events were greater at $7 \mathrm{~cm}$ depth likely as a result of the evaporation from the pot surface as well as water uptake by roots.

In addition to stable soil water content within the root zone in all the treatment pots, daily average soil temperature, a crucial factor in root development and function in the pot-in-pot system (e.g., Martin et al., 1999; Miralles et al., 2012), was similar in all the treatments during the experimental period (data not shown). This also suggested that daily average soil temperature in all the treatments was unaffected by the irrigation water or rainfall. For example, as shown in Fig. 2, temporal variations in daily average soil temperatures at $10-\mathrm{cm}$ depth during both 2009 and 2010 were similar in pots under the irrigation $\mathrm{EC}_{\text {IRR }}$ treatment levels of $3.5 \mathrm{dS} \cdot \mathrm{m}^{-1}$ and 5.5 $\mathrm{dS} \cdot \mathrm{m}^{-1}$. The variations in daily average air temperatures were slightly lower or similar to soil temperatures observed in all the treatments during the experimental period (Fig. 2). The benefit of the pot-in-pot system was that soil temperature in cultivation pots remained similar to air temperature, which, in contrast to traditional cultivation in above-ground pots, might reduce root zone temperature stress (Miralles et al., 2012; Neal, 2010; Young and Bachman, 1996).

Soil salinity $\left(\mathrm{EC}_{1: 1}\right)$ within the 0 - to $20-\mathrm{cm}$ depths was significantly higher when the irrigation $\mathrm{EC}_{\mathrm{IRR}}$ treatment levels increased from 1.4 to $7.5 \mathrm{dS} \cdot \mathrm{m}^{-1}$. The $\mathrm{EC}_{1: 1}$ data under the irrigation $\mathrm{EC}_{\mathrm{IRR}}$ levels of 1.4 (control), 3.5, 5.5 , and $7.5 \mathrm{dS} \cdot \mathrm{m}^{-1}$ were highly correlated with the $E_{d}$ data (Fig. 3). As expected, the $\mathrm{EC}_{\mathrm{d}}$ was always greater than the $\mathrm{EC}_{1: 1}$. Both $\mathrm{EC}$ values were similar when the $\mathrm{EC}_{1: 1}$ data were converted to the equivalent saturated paste (data not shown) using the relationship shown in Fig. 4. As shown in Fig. 4, the EC of $1: 1,1: 2,1: 3,1: 4,1: 5$, and $1: 10$ soil to water extracts are typically lower than those of the saturation paste as a result of increased dilution effect, which has been reported in other studies (e.g., Reitemeier, 1946; Sonneveld and Van Den Ende, 1971; Zhang et al., 2005). In particular, the EC in the saturated paste extract is 2 -fold $(\approx 1.905$ times $)$ greater than that $\left(E_{1: 1}\right)$ in the 1:1 soil:water extract (Fig. 4). Note that the relationship was based on sandy loam soils to convert the $1: 1$ results to the equivalent results of a saturated paste, and the saturated paste equivalent EC values were only used to compare with the saturated paste EC values reported in previous studies that have evaluated pecan seedlings response to irrigation water salinity. Further examination and comparison of the saturated paste and soil to water extraction methods are required for other soil textures.

Similar to the $\mathrm{EC}_{\mathrm{d}}$, the $\mathrm{EC}_{1: 1}$ differed significantly among the irrigation $\mathrm{EC}_{\mathrm{IRR}}$ treatments, but the $\mathrm{EC}_{1: 1}$ within the same $\mathrm{EC}_{\mathrm{IRR}}$ treatment level remained nearly constant during both years, indicating that drainage was adequate to allow salts to be leached below the root zone. The adequate drainage in all the treatments could be explained by the large soil pores and low water-holding capacity of the sandy loam soil, and the resulting rapid drainage could flush out the accumulated salts from the root zone soil. Soil water redistribution through the unsaturated portion of the sandy soil profile happened rapidly after irrigation events (Deb et al., 2013).

Annual changes in seedling heights and stem diameters for all the treatments, expressed as average differences of measurements made between 2 Mar. and 5 Oct. in 2009 and 22 Mar. and 9 Oct. in 2010, are shown in Fig. 5. At the onset of salinity treatments, all pecan seedlings appeared in similar physical

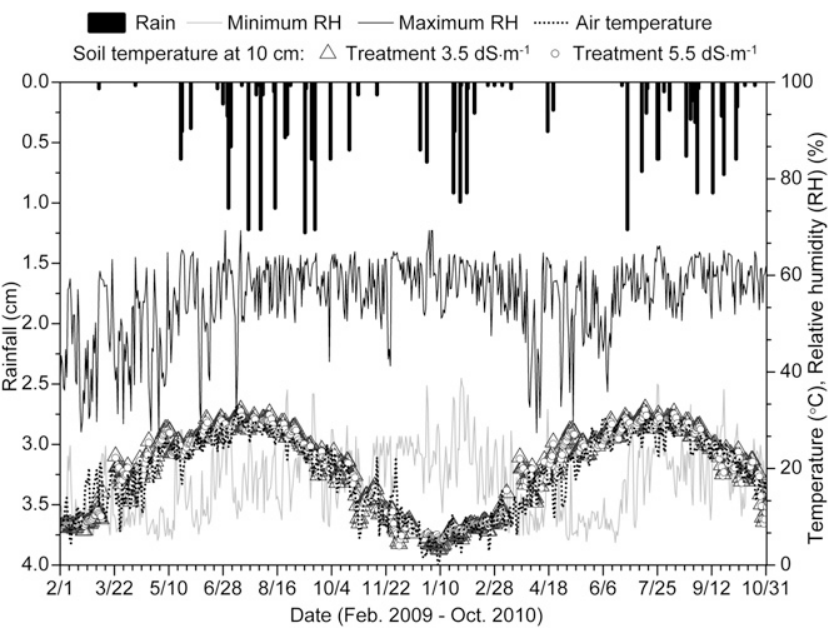

Fig. 2. Temporal variations in daily total rainfall, daily minimum and maximum relative humidity (RH), daily average air temperature as well as daily average soil temperature at $10-\mathrm{cm}$ depth in the cultivation pots with pecan (Carya illinoinensis) seedlings of rootstock 'Riverside' grafted with 'Western Schley' scions grown under the irrigation water salinity (electrical conductivity, $\mathrm{EC}_{\mathrm{IRR}}$ ) treatment levels of $3.5 \mathrm{dS} \cdot \mathrm{m}^{-1}$ and $5.5 \mathrm{dS} \cdot \mathrm{m}^{-1}$ during the experiential period from Feb. 2009 to Oct. 2010. 


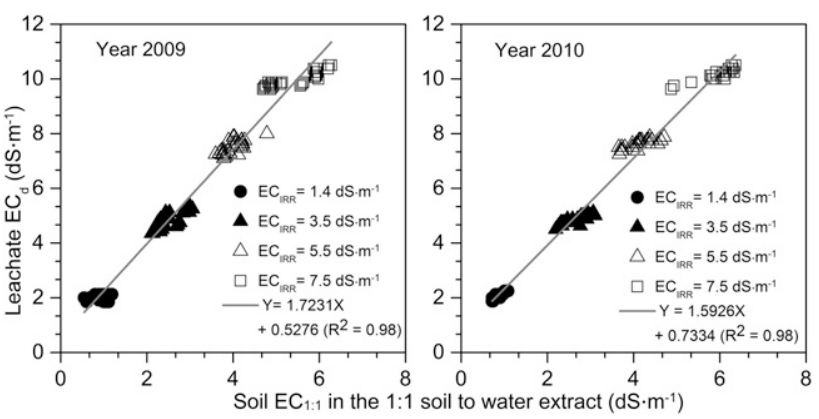

Fig. 3. Leachate electrical conductivity $\left(\mathrm{EC}_{\mathrm{d}}\right)$ as a function of the soil electrical conductivity $\left(\mathrm{EC}_{1: 1}\right)$ determined using the 1:1 soil:water method within the 0 - to 20 -cm depth in the pot-in-pot system with pecan (Carya illinoinensis) seedlings of rootstock 'Riverside' grafted with 'Western Schley' scions grown for 2 years under the irrigation water salinity (electrical conductivity, $\mathrm{EC}_{\mathrm{IRR}}$ ) treatment levels of 1.4 (control), 3.5, 5.5, and $7.5 \mathrm{dS} \cdot \mathrm{m}^{-1}$. The monthly data for all the treatment pots from May to September during the 2009 and 2010 growing seasons are presented.

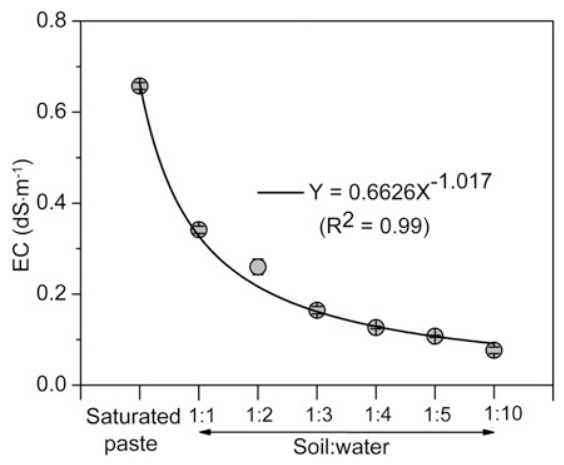

Fig. 4. Soil electrical conductivity (EC) levels determined using the saturated paste extract and $1: 1,1: 2,1: 3,1: 4,1: 5$, and $1: 10$ soil:water methods. Error bars are sEMS.

condition and average plant height and stem diameter measured on 2 Mar. 2009 were $25.5 \mathrm{~cm}$ and $12.9 \mathrm{~mm}$, respectively. Increasing salinity in irrigation water, specifically the irrigation $\mathrm{EC}_{\mathrm{IRR}}$ treatment levels of 5.5 and $7.5 \mathrm{dS} \cdot \mathrm{m}^{-1}$, significantly decreased the height and stem diameter growth of the seedlings $(P \leq 0.05)$, indicating an inverse trend between plant or diameter growth and irrigation water salinity levels (Fig. 5). However, annual changes in heights and stem diameters of the seedlings under the irrigation $\mathrm{EC}_{\mathrm{IRR}}$ treatment levels of 1.4 and $3.5 \mathrm{dS} \cdot \mathrm{m}^{-1}$ were not statistically significant between the years. The threshold soil salinity falls between 1.4- and 3.5-dS. $\mathrm{m}^{-1} \mathrm{EC}_{\mathrm{IRR}}$ treatments. Using the relationship in Fig. 4 to convert $\mathrm{EC}_{1: 1}$ to saturated paste EC (1.70 and $\left.5.16 \mathrm{dS} \cdot \mathrm{m}^{-1}\right)$ shows that these values are within the threshold soil salinity reported by Miyamoto et al. (1985) for seedlings of pecan rootstock cultivars in lysimeter experiments. Miyamoto et al. (1985) observed that pecan seedlings growth in fine loamy sand during a 2-year period was reduced significantly when the soil salinity of the soil saturation extract exceeded $3.3 \mathrm{dS} \cdot \mathrm{m}^{-1}$ in a confined root zone depth of $50 \mathrm{~cm}$.

From May to September in 2009, for the irrigation $\mathrm{EC}_{\mathrm{IRR}}$ treatment level of $3.5 \mathrm{dS} \cdot \mathrm{m}^{-1}$, annual mean values of $\mathrm{EC}_{1: 1}$ and $\mathrm{EC}_{\mathrm{d}}$ were $2.51 \mathrm{dS} \cdot \mathrm{m}^{-1}$ and $4.81 \mathrm{dS} \cdot \mathrm{m}^{-1}$, respectively (Tables 1 and 2; Fig. 3). During this period in 2009 , the respective mean values of $\mathrm{EC}_{1: 1}$ and $\mathrm{EC}_{\mathrm{d}}$ for the control $\left(\mathrm{EC}_{\mathrm{IRR}}=1.4 \mathrm{dS} \cdot \mathrm{m}^{-1}\right)$ treatment were $0.94 \mathrm{dS} \cdot \mathrm{m}^{-1}$ and $2.01 \mathrm{dS} \cdot \mathrm{m}^{-1}$. The respective mean values of $\mathrm{EC}_{1: 1}$ and $\mathrm{EC}_{\mathrm{d}}$ for the control $\left(\mathrm{EC}_{\mathrm{IRR}}=1.4 \mathrm{dS} \cdot \mathrm{m}^{-1}\right)$ treatment during 2010 were $0.89 \mathrm{dS} \cdot \mathrm{m}^{-1}$ and $2.10 \mathrm{dS} \cdot \mathrm{m}^{-1}$. The mean $\mathrm{EC}_{1: 1}$ and $\mathrm{EC}_{\mathrm{d}}$ for the $\mathrm{EC}_{\mathrm{IRR}}$ treatment level of $3.5 \mathrm{dS} \cdot \mathrm{m}^{-1}$ during 2010 were $2.71 \mathrm{dS} \cdot \mathrm{m}^{-1}$ and $4.86 \mathrm{dS} \cdot \mathrm{m}^{-1}$, respectively (Tables 1 and 2; Fig. 3). Similar $\mathrm{EC}_{1: 1}$ values within the same salinity treatment level during both years suggest that the height and stem diameter of the seedlings decreased somewhere between 0.89 and 2.71 $\mathrm{dS} \cdot \mathrm{m}^{-1}$ (equivalent $\mathrm{EC}$ in the saturated paste extract somewhere between 1.70 and 5.16 $\mathrm{dS} \cdot \mathrm{m}^{-1}$ or $\mathrm{EC}_{\mathrm{d}}$ somewhere between 2.10 and $\left.4.86 \mathrm{dS} \cdot \mathrm{m}^{-1}\right)$. This occurred when the soil water content was not a limiting factor and irrigation water was uniformly distributed in the confined root zone to obtain uniform salt leaching.

Compared with the control treatment (1.4 $\mathrm{dS} \cdot \mathrm{m}^{-1}$ ), increasing salinity in irrigation water affected the timing of budbreak with delays of up to 2 weeks, particularly for the irrigation $\mathrm{EC}_{\mathrm{IRR}}$ treatment levels of 5.5 and $7.5 \mathrm{dS} \cdot \mathrm{m}^{-1}$ in 2009 (Table 3). The irrigation $\mathrm{EC}_{\text {IRR }}$ treatment level of $3.5 \mathrm{dS} \cdot \mathrm{m}^{-1}$ did not affect the timing of the budbreak compared with the control treatment $\left(1.4 \mathrm{dS} \cdot \mathrm{m}^{-1}\right)$ except for two pots, which was delayed by as much as 1 week in the first year. Seedling leaf scorch symptoms first appeared on individual leaves between 3 and 12 Aug. 2009 for all pots under the irrigation $\mathrm{EC}_{\mathrm{IRR}}$ treatment levels of 5.5 and $7.5 \mathrm{dS} \cdot \mathrm{m}^{-1}$ (Table 3). These leaf scorch symptoms started with the tips of leaves burning or turning light gray-green, which advanced along the margins of the leaves, but the midrib of the leaf was green at the time of leaf harvest on 5 Oct. 2009. The scorching also appeared on leaves in two pots under the irrigation $\mathrm{EC}_{\mathrm{IRR}}$ treatment level of $3.5 \mathrm{dS} \cdot \mathrm{m}^{-1}$. Leaf scorch symptoms were seen in these two seedlings 1 week later than the irrigation $\mathrm{EC}_{\mathrm{IRR}}$ treatments of 5.5 and 7.5 $\mathrm{dS} \cdot \mathrm{m}^{-1}$.

During 2010, increasing irrigation salinity delayed as well as inhibited budbreak in seedlings under the irrigation $\mathrm{EC}_{\mathrm{IRR}}$ treatment levels of 5.5 and $7.5 \mathrm{dS} \cdot \mathrm{m}^{-1}$ (Table 4). Because of similar timing of budbreak for the $\mathrm{EC}_{\text {IRR }}$ treatment levels of 1.4 (control) and $3.5 \mathrm{dS} \cdot \mathrm{m}^{-1}$ during both years, budbreak might be inhibited in pecan seedlings at the soil salinity observed between the 1.4- and 3.5-dS. $\mathrm{m}^{-1} \mathrm{EC}_{\mathrm{IRR}}$ treatments, i.e., the $\mathrm{EC}_{1: 1}$ somewhere between 0.89 and $2.71 \mathrm{dS} \cdot \mathrm{m}^{-1}$ (equivalent $\mathrm{EC}$ in the saturated paste extract somewhere between 1.70 and $5.16 \mathrm{dS} \cdot \mathrm{m}^{-1}$ or $\mathrm{EC}_{\mathrm{d}}$ somewhere between 2.10 and 4.86 $\mathrm{dS} \cdot \mathrm{m}^{-1}$ ). During 2010 , leaf scorch symptoms were again noticed on 25 July, 5 Aug., and $22 \mathrm{Aug}$. in all the seedlings under the irrigation $\mathrm{EC}_{\mathrm{IRR}}$ treatment levels of 7.5, 5.5, and 3.5 $\mathrm{dS} \cdot \mathrm{m}^{-1}$, respectively (Table 4). Leaf scorch rated visually ranged from 0 to $1.2,2.0$ to 3.2, and 3.0 to 3.3 on a scale of 0 to 5 in pecan seedlings grown for 2 years under the irrigation $\mathrm{EC}_{\mathrm{IRR}}$ treatment levels of 3.5, 5.5, and 7.5 $\mathrm{dS} \cdot \mathrm{m}^{-1}$, respectively (Tables 3 and 4). No leaf scorch symptoms were seen in pecan seedlings under the control treatment $\left(\mathrm{EC}_{\mathrm{IRR}}=\right.$ $1.4 \mathrm{dS} \cdot \mathrm{m}^{-1}$ ) during both years. It was determined that the leaf scorch symptoms were abiotic, i.e., were not pecan bacterial leaf scorch caused by Xylella fastidiosa (Sanderlin and Heyderich-Alger, 2000), but only as a result of the salt stress imposed on pecan seedlings under irrigation $\mathrm{EC}_{\mathrm{IRR}}$ treatment levels of $7.5,5.5$, and $3.5 \mathrm{dS} \cdot \mathrm{m}^{-1}$. A laboratory test at New Mexico State University's Plant Diagnostic Clinic could not detect the presence of Xylella fastidiosa in scorched leaves by polymerase chain reaction (Randall et al., 2009).

In pecan seedlings with scorched leaves resulting from salt injury, it appeared that leaf chloride $\left(\mathrm{Cl}^{-}\right)$was significantly higher compared with the control treatment, indicating that $\mathrm{Cl}^{-}$ions were readily translocated to the leaves (Fig. 6B). Even at the control treatment $\left(1.4 \mathrm{dS} \cdot \mathrm{m}^{-1}\right)$, no pecan seedlings had the ability to exclude $\mathrm{Cl}^{-}$accumulation from its leaves. During both years, increasing salinity levels of irrigation water, particularly the irrigation $\mathrm{EC}_{\mathrm{IRR}}$ treatment levels of 5.5 and $7.5 \mathrm{dS} \cdot \mathrm{m}^{-1}$ tended to increase leaf $\mathrm{Cl}^{-}$significantly (Fig. 6B). In contrast, increasing irrigation salinity $\left(\mathrm{EC}_{\mathrm{IRR}}\right)$ levels reduced $\mathrm{N}$ accumulation in leaves (Fig. 6A). These results also suggested the disturbance of the mechanism controlling the translocation of $\mathrm{N}$ to the leaves by increasing irrigation salinity treatments. In short-term greenhouse experiments, Faruque (1968) and Hanna (1972) reported that $\mathrm{Cl}^{-}$was exclusively responsible for leaf injury of pecan seedlings grown in gravel-nutrient solution. On the contrary, in a 2-year lysimeter experiment, Miyamoto et al. (1985) reported the poor correlation between pecan seedling growth and $\mathrm{Cl}^{-}$in leaves or in soil solutions. The reduction in pecan seedling growth was attributed more to $\mathrm{Na}^{+}$than to $\mathrm{Cl}^{-}$ accumulation in leaves and primarily in soil solutions when $\mathrm{Na}^{+}$was the main cation and soil water depletion did not exceed $50 \%$ of the available water (Miyamoto et al., 1985). However, pecan seedlings subjected to shortterm exposure to saline solution are susceptible to acute effects of $\mathrm{Cl}^{-}$ions, whereas the 


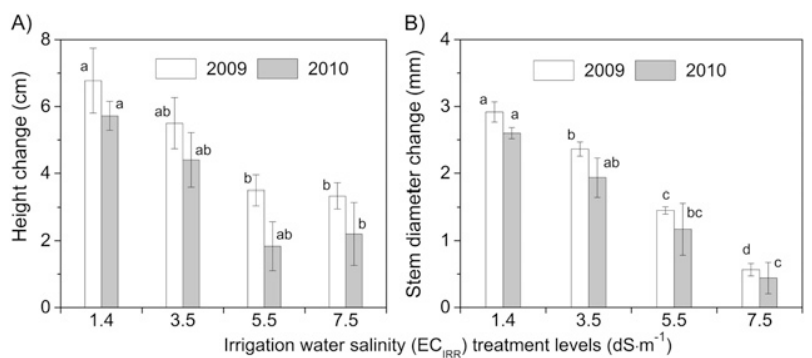

Fig. 5. Annual changes in (A) heights and (B) stem diameters of pecan (Carya illinoinensis) seedlings of rootstock 'Riverside' grafted with 'Western Schley' scions grown in the pot-in-pot system under the irrigation water salinity (electrical conductivity, $\mathrm{EC}_{\mathrm{IRR}}$ ) treatment levels of 1.4 (control), 3.5, 5.5 and $7.5 \mathrm{dS} \cdot \mathrm{m}^{-1}$. Error bars are SEMS. Data for each treatment represent average differences between values measured on 2 Mar. and 5 Oct. during 2009 and 22 Mar. and 9 Oct. during 2010. For each year, mean values followed by the same letter or letters are not significantly different $(P \leq 0.05)$ based on Tukey's test.

Table 3. Evolution of budbreak and leaf scorch symptoms in pecan (Carya illinoinensis) seedlings of rootstock 'Riverside' grafted with 'Western Schley' scions grown in the pot-in-pot system under the irrigation water salinity (electrical conductivity, $\mathrm{EC}_{\mathrm{IRR}}$ ) treatment levels of 1.4 (control), 3.5, 5.5, and $7.5 \mathrm{dS} \cdot \mathrm{m}^{-1}$ during the 2009 growing season.

\begin{tabular}{|c|c|c|c|c|c|}
\hline \multirow[b]{2}{*}{$\mathrm{EC}_{\text {IRR }}\left(\mathrm{dS} \cdot \mathrm{m}^{-1}\right)$} & \multirow[b]{2}{*}{ Pot (seedling no.) } & \multicolumn{2}{|c|}{ Date first seen } & \multirow{2}{*}{$\begin{array}{l}\text { Scorching } \\
\text { severity }\end{array}$} & \multirow{2}{*}{$\begin{array}{l}\text { Seedling } \\
\text { Survival }\end{array}$} \\
\hline & & Bud break ${ }^{z}$ & Leaf scorch symptom & & \\
\hline$\overline{1.4}$ & 1 & 8 Apr. & Not seen & 0 & Yes \\
\hline 1.4 & 2 & 8 Apr. & Not seen & 0 & Yes \\
\hline 1.4 & 3 & 8 Apr. & Not seen & 0 & Yes \\
\hline 1.4 & 4 & 8 Apr. & Not seen & 0 & Yes \\
\hline 1.4 & 5 & 8 Apr. & Not seen & 0 & Yes \\
\hline 1.4 & 6 & 8 Apr. & Not seen & 0 & Yes \\
\hline 3.5 & 7 & 15 Apr. & 25 Aug. & 1.0 & Yes \\
\hline 3.5 & 8 & 8 Apr. & Not seen & 0 & Yes \\
\hline 3.5 & 9 & 14 Apr. & 25 Aug. & 1.2 & Yes \\
\hline 3.5 & 10 & 8 Apr. & Not seen & 0 & Yes \\
\hline 3.5 & 11 & 8 Apr. & Not seen & 0 & Yes \\
\hline 3.5 & 12 & 8 Apr. & Not seen & 0 & Yes \\
\hline 5.5 & 13 & 23 Apr. & 10 Aug. & 3.0 & Yes \\
\hline 5.5 & 14 & 23 Apr. & 10 Aug. & 3.0 & Yes \\
\hline 5.5 & 15 & 26 Apr. & 10 Aug. & 2.5 & Yes \\
\hline 5.5 & 16 & 25 Apr. & 10 Aug. & 2.0 & Yes \\
\hline 5.5 & 17 & 25 Apr. & 10 Aug. & 2.5 & Yes \\
\hline 5.5 & 18 & 23 Apr. & 10 Aug. & 3.1 & Yes \\
\hline 7.5 & 19 & 24 Apr. & 3 Aug. & 3.2 & Yes \\
\hline 7.5 & 20 & 24 Apr. & 3 Aug. & 3.2 & Yes \\
\hline 7.5 & 21 & 24 Apr. & 3 Aug. & 3.2 & Yes \\
\hline 7.5 & 22 & 24 Apr. & 3 Aug. & 3.0 & Yes \\
\hline 7.5 & 23 & 27 Apr. & 3 Aug. & 3.2 & Yes \\
\hline 7.5 & 24 & 27 Apr. & 3 Aug. & 3.2 & Yes \\
\hline
\end{tabular}

${ }^{2}$ Date recorded when the bud scales split and the leaf began to expand.

${ }^{\mathrm{y}}$ Evaluated visually on a scale of 0 to 5 , where $0=$ no scorching, $1=$ insignificant scorching, $2=25 \%$ of leaf area scorched, $3=50 \%$ of leaf area scorched, $4=75 \%$ of leaf area scorched, and $5=$ all the leaf area scorched or dead leaf.

long-term effect on tree growth is associated more often with $\mathrm{Na}^{+}$(Miyamoto et al., 1985; Miyamoto and Nesbitt, 2011).

In our pot-in-pot experiment, pronounced soil water stress did not develop for the sandy loam soil because of the same amount of irrigation water was frequently applied to all the seedlings under all the treatments. To impose salt stress in the root zone, $\mathrm{Na}^{+}$proportions in the irrigation water salinity levels of $3.5,5.5$, and $7.5 \mathrm{dS} \cdot \mathrm{m}^{-1}$ were decreased by using a solution of $\mathrm{CaCl}_{2}$ and $\mathrm{NaCl}$ in a ratio of 2:1 (by weight). Therefore, leaf scorch symptoms in pecan seedlings resulting from salt injury in our experiment perhaps associated with $\mathrm{Cl}^{-}$toxicity because increased $\mathrm{Cl}^{-}$uptake resulted in both $\mathrm{Cl}^{-}$accumulation and scorching in leaves (Fig. 6B; Tables 3 and 4). This might also explain the decreased $\mathrm{N}$ contents in seedling leaves with the increase in the irrigation $\mathrm{EC}_{\text {IRR }}$ levels (Fig. 6A). The decrease in $\mathrm{N}$ contents could be caused by an antagonistic interaction between $\mathrm{Cl}^{-}$and the chemical form of $\mathrm{N}$ such as $\mathrm{NO}_{3}{ }^{-}$in their uptake processes in root. Several studies for other plants reported that $\mathrm{NO}_{3}{ }^{-}$uptake could be inhibited by salinity through a restriction of the $\mathrm{NO}_{3}{ }^{-}$transporter activity, which is more sensitive to $\mathrm{Cl}^{-}$than $\mathrm{Na}^{+}$(e.g., Aslam et al., 1984; Tuna et al., 2007, 2008). However, further studies are needed for the mechanistic explanations of the contributions of $\mathrm{Cl}^{-}$ions to pecan seedling growth reduction, delayed budbreak or bud failures, and leaf scorch symptoms under the high irrigation $\mathrm{EC}_{\mathrm{IRR}}$ levels, particularly 5.5 and $7.5 \mathrm{dS} \cdot \mathrm{m}^{-1}$ or higher.
As mentioned earlier, the annual changes in seedling heights and stem diameters were not significantly different (Fig. 5) and the timing of budbreak was similar (Tables 3 and 4) under irrigation $\mathrm{EC}_{\mathrm{IRR}}$ treatment levels of 1.4 and $3.5 \mathrm{dS} \cdot \mathrm{m}^{-1}$. Nevertheless, the annual mean soil salinity $\left(\mathrm{EC}_{1: 1}\right)$ value of $2.71 \mathrm{dS} \cdot \mathrm{m}^{-1}$ (equivalent to $\mathrm{EC}$ of $5.16 \mathrm{dS} \cdot \mathrm{m}^{-1}$ in the saturated paste extract or $\mathrm{EC}_{\mathrm{d}}$ of $4.86 \mathrm{dS} \cdot \mathrm{m}^{-1}$ ) under the irrigation $\mathrm{EC}_{\mathrm{IRR}}$ treatment level of $3.5 \mathrm{dS} \cdot \mathrm{m}^{-1}$ displayed clear visual symptoms of salt injury or scorch in the leaves (Fig. 3; Tables 3 and 4). As presented in Table 4, no pecan seedlings under the irrigation $\mathrm{EC}_{\mathrm{IRR}}$ treatment levels of 5.5 and $7.5 \mathrm{dS} \cdot \mathrm{m}^{-1}$ survived to the end of the 2-year growing period. For these $\mathrm{EC}_{\mathrm{IRR}}$ treatment levels, the respective annual mean values of $\mathrm{EC}_{1: 1}$ and $\mathrm{EC}_{\mathrm{d}}$ ranged from 4.01 to $5.44 \mathrm{dS} \cdot \mathrm{m}^{-1}$ and 7.50 to $9.98 \mathrm{dS} \cdot \mathrm{m}^{-1}$ during 2009 and from 4.16 to 5.94 $\mathrm{dS} \cdot \mathrm{m}^{-1}$ and 7.65 to $10.2 \mathrm{dS} \cdot \mathrm{m}^{-1}$ during 2010 (Tables 1 and 2; Fig. 3). Therefore, the soil salinity range observed between the 1.4- and 3.5-dS. $\mathrm{m}^{-1} \mathrm{EC}_{\mathrm{IRR}}$ treatments, i.e., the $\mathrm{EC}_{1: 1}$ somewhere between 0.89 and $2.71 \mathrm{dS} \cdot \mathrm{m}^{-1}$ (equivalent $\mathrm{EC}$ in the saturated paste extract somewhere between 1.70 and $5.16 \mathrm{dS} \cdot \mathrm{m}^{-1}$ or $\mathrm{EC}_{\mathrm{d}}$ somewhere between 2.10 and 4.86 $\mathrm{dS} \cdot \mathrm{m}^{-1}$ ), could be hazardous for the survival of pecan seedlings. These $\mathrm{EC}_{1: 1}$ values under the 1.4 and $3.5 \mathrm{dS} \cdot \mathrm{m}^{-1} \mathrm{EC}_{\mathrm{IRR}}$ treatments were within the threshold range that has been observed by Miyamoto et al. (1985) in the lysimeter experiment for pecan rootstock cultivars. Miyamoto et al. (1985) reported that the minimal pecan seedling growth was at soil salinity of $5.2 \mathrm{dS} \cdot \mathrm{m}^{-1}$ in the saturation extract and seedling tip dieback was at $8.5 \mathrm{dS} \cdot \mathrm{m}^{-1}$.

Responses of pecan seedlings to irrigation water salinity observed in our pot-in-pot experiment may not be directly applicable to nut-producing trees. The concentration of saline irrigation water in the confined root zone systems of cultivation pots might magnify the symptoms. Therefore, salinity effects in pecan seedlings could be more pronounced than those in nut-producing trees grown in the orchard where roots are growing in a much larger volume of soil with lower average salt concentrations. However, our observations provide essential information regarding the salinity response and salinity-related suppression of budbreak of grafted seedlings to irrigation water salinity levels. Note that it was not the intent of our pot-in-pot experiments to improve the irrigation application efficiency, and therefore, a large amount of irrigation water was frequently applied to prevent soil water stress as well as obtain leaching of salts from the soil profile. Further experiments are needed to find an optimum balance between the desired leaching fractions to achieve specific levels of soil salinity and irrigation efficiency to optimize the water needed for the pot-in-pot pecan production.

\section{Conclusions}

Salinity responses of drip-irrigated pecan seedlings grown in the pot-in-pot system under irrigation water salinity $\left(\mathrm{EC}_{\mathrm{IRR}}\right)$ treatment 
Table 4. Evolution of budbreak and leaf scorch symptoms in pecan (Carya illinoinensis) seedlings of rootstock 'Riverside' grafted with 'Western Schley' scions grown in the pot-in-pot system under the irrigation water salinity (electrical conductivity, $\mathrm{EC}_{\mathrm{IRR}}$ ) treatment levels of 1.4 (control), 3.5, 5.5, and $7.5 \mathrm{dS} \cdot \mathrm{m}^{-1}$ during the 2010 growing season.

\begin{tabular}{lccccc}
\hline & & \multicolumn{2}{c}{ Date first seen } & Scorching & Seedling \\
\cline { 2 - 4 } $\mathrm{EC}_{\text {IRR }}\left(\mathrm{dS} \cdot \mathrm{m}^{-1}\right)$ & Pot (seedling no.) & Bud break & Leaf scorch symptom & Survival \\
\hline 1.4 & 1 & 1 Apr. & Not seen & 0 & Yes \\
1.4 & 2 & 1 Apr. & Not seen & 0 & Yes \\
1.4 & 3 & 3 Apr. & Not seen & 0 & Yes \\
1.4 & 4 & 1 Apr. & Not seen & 0 & Yes \\
1.4 & 5 & 1 Apr. & Not seen & 0 & Yes \\
1.4 & 6 & 1 Apr. & Not seen & 0 & Yes \\
3.5 & 7 & 3 Apr. & 22 Aug. & 1.0 & Yes \\
3.5 & 8 & 3 Apr. & 22 Aug. & 1.0 & Yes \\
3.5 & 9 & 1 Apr. & 22 Aug. & 1.0 & Yes \\
3.5 & 10 & 1 Apr. & 22 Aug. & 1.2 & Yes \\
3.5 & 11 & 1 Apr. & 22 Aug. & 1.2 & Yes \\
3.5 & 12 & 1 Apr. & 22 Aug. & 1.0 & Yes \\
5.5 & 13 & None & None & None & No \\
5.5 & 14 & None & None & None & No \\
5.5 & 15 & 17 Apr. & 5 Aug. & 3.0 & No \\
5.5 & 16 & 18 Apr. & 5 Aug. & 3.0 & No \\
5.5 & 17 & 18 Apr. & 5 Aug. & 3.0 & No \\
5.5 & 18 & 18 Apr. & 5 July & 3.2 & No \\
7.5 & 19 & None & None & None & No \\
7.5 & 20 & None & None & None & No \\
7.5 & 21 & None & None & None & No \\
7.5 & 22 & 18 Apr. & 25 July & 3.2 & No \\
7.5 & 23 & 18 Apr. & 25 July & 3.2 & No \\
7.5 & 24 & 18 Apr. & 25 July & 3.3 & No \\
\hline
\end{tabular}

${ }^{2}$ Date recorded when the bud scales split and the leaf began to expand.

${ }^{y}$ Evaluated visually on a scale of 0 to 5 , where $0=$ no scorching, $1=$ insignificant scorching, $2=25 \%$ of leaf area scorched, $3=50 \%$ of leaf area scorched, $4=75 \%$ of leaf area scorched, and $5=$ all the leaf area scorched or dead leaf.

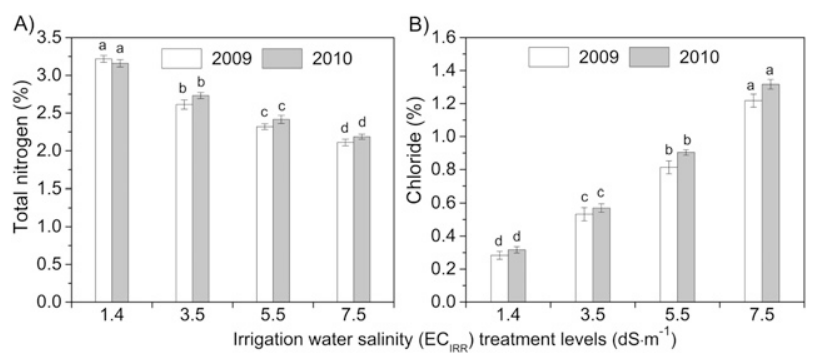

Fig. 6. (A) Total nitrogen $(\mathrm{N})$ and $(\mathbf{B})$ chloride $\left(\mathrm{Cl}^{-}\right)$in leaves of pecan (Carya illinoinensis) seedlings of rootstock 'Riverside' grafted with 'Western Schley' scions grown in the pot-in-pot system under the irrigation salinity (electrical conductivity, $\mathrm{EC}_{\mathrm{IRR}}$ ) treatment levels of 1.4 (control), 3.5, 5.5 and $7.5 \mathrm{dS} \cdot \mathrm{m}^{-1}$. Data are the average values measured at the end of growing season in 2009 and in 2010 . Error bars are SEMS. For each year, mean values followed by the same letter are not significantly different $(P \leq 0.05)$ based on Tukey's test.

levels of 1.4 (control), 3.5, 5.5, and $7.5 \mathrm{dS} \cdot \mathrm{m}^{-1}$ were compared. The leachate $\mathrm{EC}\left(\mathrm{EC}_{\mathrm{d}}\right)$ was highly correlated with soil salinity $\left(\mathrm{EC}_{1: 1}\right)$ under all the treatments and was significantly higher when the irrigation $\mathrm{EC}_{\mathrm{IRR}}$ treatment levels increased from 1.4 (control) to $7.5 \mathrm{dS} \cdot \mathrm{m}^{-1}$. Compared with the control treatment, increasing irrigation salinity, particularly the irrigation $\mathrm{EC}_{\mathrm{IRR}}$ treatment levels of 5.5 and $7.5 \mathrm{dS} \cdot \mathrm{m}^{-1}$, significantly decreased the heights and stem diameters of the seedlings and delayed or inhibited budbreak in seedlings. The soil salinity $\left(\mathrm{EC}_{1: 1}\right)$ that inhibited the height and stem diameter growth of the seedlings and budbreak was somewhere between 0.89 and $2.71 \mathrm{dS} \cdot \mathrm{m}^{-1}$ (equivalent $\mathrm{EC}$ in the saturated paste extract somewhere between 1.70 and $5.16 \mathrm{dS} \cdot \mathrm{m}^{-1}$ or $\mathrm{EC}_{\mathrm{d}}$ somewhere between 2.10 and $4.86 \mathrm{dS} \cdot \mathrm{m}^{-1}$ ), leaves, suggesting the disturbance of the mechanism controlling the translocation of $\mathrm{N}$ to the leaves by increasing irrigation salinity treatments. Leaf scorch symptoms in pecan seedlings resulting from salt injury were likely to be associated with $\mathrm{Cl}^{-}$toxicity because an increase in $\mathrm{Cl}^{-}$uptake might result in both $\mathrm{Cl}^{-}$ accumulation in the leaf tissues and scorched leaves. The decreased $\mathrm{N}$ contents in seedling leaves with the increase in $\mathrm{EC}_{\mathrm{IRR}}$ levels could be caused by an antagonistic interaction between $\mathrm{Cl}^{-}$and the chemical form of $\mathrm{N}$ such as $\mathrm{NO}_{3}{ }^{-}$in their uptake processes in root. No pecan seedlings under the irrigation $\mathrm{EC}_{\mathrm{IRR}}$ treatment levels of 5.5 and $7.5 \mathrm{dS} \cdot \mathrm{m}^{-1}$ survived to the end of the 2-year growing period, suggesting that the soil salinity range observed between the 1.4- and 3.5-dS. $\mathrm{m}^{-1} \mathrm{EC}_{\mathrm{IRR}}$ treatments (or $\mathrm{EC}_{1: 1}$ somewhere between 0.89 and $2.71 \mathrm{dS} \cdot \mathrm{m}^{-1}$ ) could be hazardous for the survival of pecan seedlings. Further research is needed for the mechanistic explanations of contributions of $\mathrm{Cl}^{-}$ions to pecan seedling growth reduction, delayed budbreak or bud failures, and leaf scorch symptoms under high irrigation $\mathrm{EC}_{\mathrm{IRR}}$ levels of 5.5 and $7.5 \mathrm{dS} \cdot \mathrm{m}^{-1}$ or higher.

\section{Literature Cited}

Allen, R.G. 1999. Instructions for attaching soil water resistance blocks to the Onset Hobo H-08 4-Channel External Soil Moisture Logger (or the single channel data Hobo logger). University of Idaho, Kimberly, ID. 13 Feb. 2013. $<$ http://www.kimberly.uidaho.edu/water/swm/ WM_Hobo2.htm>.

Aslam, M., R.C. Huffaker, and D.W. Rains. 1984. Early effects of salinity on nitrate assimilation in barley seedlings. Plant Physiol. 76: 321-325.

Catlin, P.B., G.J. Hoffman, R.M. Mead, and R.S. Johnson. 1993. Long-term response of mature plum trees to salinity. Irrig. Sci. 13:171-176.

Deb, S.K., M.K. Shukla, and J.G. Mexal. 2011. Numerical modeling of water fluxes in the root zone of a mature pecan orchard. Soil Sci. Soc. Amer. J. 75:1667-1680.

Deb, S.K., M.K. Shukla, P. Sharma, and J.G. Mexal. 2013. Soil water depletion in irrigated mature pecans under contrasting soil textures for arid southern New Mexico. Irrig. Sci. 31:69-85.

Faruque, A.H.M. 1968. The effect of salinity on phytotoxicity and ion uptake of pecan seedlings (Carya illinoensis Wag. cv. Riverside). PhD diss., Texas A\&M University, College Station, TX.

Fowler, D.B. and J.W. Hamm. 1980. Crop response to saline soil conditions in the parkland area of Saskatchewan. Can. J. Soil Sci. 60:439-449.

Gee, G.W. and J.W. Bauder. 1986. Particle-size analysis, p. 383-411. In: Klute, A. (ed.). Methods of soil analysis, Part 1. 2nd Ed. Agron. Monogr. 9, Amer. Soc. Agron. and Soil Sci. Soc. Amer., Madison, WI.

Hanna, D.J. 1972. Absorption and accumulation of chloride ions by pecan (Carya illinoensis Koch) seedling rootstocks. $\mathrm{PhD}$ diss., Texas A\&M University, College Station, TX.

$\mathrm{Ku}$, C.S.M. and D.R. Hershey. 1991. Leachate electrical conductivity and growth of potted poinsettia with leaching fractions of 0 to 0.4 . J. Amer. Soc. Hort. Sci. 116:802-806.

$\mathrm{Ku}$, C.S.M. and D.R. Hershey. 1992. Leachate electrical conductivity and growth of potted geranium with leaching fractions of 0 to 0.4 . J. Amer. Soc. Hort. Sci. 117:893-897. 
Martin, C.A., L.B. McDowell, and S. Bhattacharya. 1999. Below ground pot-in-pot effects on growth of two southwest landscape trees was related to root membrane thermostability. J. Environ. Hort. 17:63-68.

Miralles, J., R. Valdes, J.J. Martínez-Sánchez, and S. Bañón. 2012. Pot-in-pot reduces salinity, chloride uptake, and maintains aesthetic value in Euonymus japonicus Thunb. under saline irrigation. HortScience 47:607-613.

Miyamoto, S. and G. Gobran. 1983. Assessment and potential remedies of salinity problems in pecan orchards of the middle Rio Grande Basin. Proc. West. Pecan Conf., Las Cruces, NM. p. 1-12.

Miyamoto, S., G. Gobran, and K. Piela. 1985. Salt effects on seedling growth and ion uptake of three pecan rootstock cultivars. Agron. J. 77: 383-388.

Miyamoto, S., J. Henggeler, and J.B. Storey. 1995. Water management in irrigated pecan orchards in the southwestern United States. HortTechnology 5:214-218.

Miyamoto, S. and M. Nesbitt. 2011. Effectiveness of soil salinity management practices in basinirrigated pecan orchards. HortTechnology 21: 569-576.

Miyamoto, S., T. Riley, G. Gobran, and J. Petticrew. 1986. Effects of saline water irrigation on soil salinity, pecan tree growth and nut production. Irrig. Sci. 7:83-95.

Miyamoto, S. and J.B. Storey. 1995. Soil management in irrigated pecan orchards in the southwestern United States. HortTechnology 5:219-222.

Neal, C.A. 2010. Crabapple and lilac growth and root-zone temperatures in northern nursery production systems. HortScience 45:30-35.

Niu, G., D.S. Rodriguez, and L. Aguiniga. 2007a. Growth and landscape performance of ten herbaceous species in response to saline water irrigation. J. Environ. Hort. 25:204-210.

Niu, G., D.S. Rodriguez, L. Aguiniga, and W. Mackay. 2007b. Salinity tolerance of Lupinus havardii and Lupinus texensis. HortScience 42:526-528.

Picchioni, G.A., H. Karaca, L.G. Boyse, B.D. McCaslin, and E.A. Herrera. 2000. Salinity, boron, and irrigated pecan productivity along New Mexico's Rio Grande Basin. J. Environ. Qual. 29:955-963.

Randall, J.J., N.P. Goldberg, J.D. Kemp, M. Radionenko, J.M. French, M.W. Olsen, and S.F. Hanson. 2009. Genetic analysis of a novel Xylella fastidiosa subspecies found in the southwestern United States. Appl. Environ. Microbiol. 75:5631-5638.

Reitemeier, R.F. 1946. Effect of moisture content on the dissolved and exchangeable ions of soils of arid regions. Soil Sci. 61:195-214.

Sanderlin, R.S. and K.I. Heyderich-Alger. 2000. Evidence that Xylella fastidiosa can cause leaf scorch disease of pecan. Plant Dis. 84:12821286.

Scanlon, B.R. and B.J. Andraski. 2002. Miscellaneous methods for measuring matric and water potential, p. 643-670. In: Dane, J.H. and G.C. Topp (eds.). Methods of soil analysis, Part 4 -Physical methods. Soil Sci. Soc. Amer. Book Series: 5, Madison, WI.

Shock, C.C., J.M. Barnum, and M. Seddigh. 1998. Calibration of Watermark soil moisture sensors for irrigation management. Proc. of the 1998 Annual Meeting of the Irrig. Assoc., San Diego, CA, 1-3 Nov. 1998. p. 139-146.

Sonneveld, C. and J. Van Den Ende. 1971. Soil analysis by means of 1:2 a volume extract. Plant Soil 35:505-516.

St. Hilaire, R., C.F. Feser, T.W. Sammis, and A.S. St. Hilaire. 2003. A system to measure evapotranspiration of in-ground container plants of Mexican elder. HortTechnology 13:185-189.

Thompson, R.B., M. Gallardo, T. Agüera, L.C. Valdez, and M.D. Fernández. 2006. Evaluation of the watermark sensor for use with drip irrigated vegetable crops. Irrig. Sci. 24:185202.

Tuna, A.L., C. Kay, M. Ashraf, H. Altunlu, I. Yokas, and B. Yagmur. 2007. The effects of calcium sulphate on growth, membrane stability and nutrient uptake of tomato plants grown under salt stress. Environ. Exp. Bot. 59:173-178.

Tuna, A.L., C. Kay, M. Dikilitas, and D. Higgs. 2008. The combined effects of gibberellic acid and salinity on some antioxidant enzyme activities, plant growth parameters and nutritional status in maize plants. Environ. Exp. Bot. 62:1-9.

van Genuchten, M.Th. 1980. A closed-form equation for predicting the hydraulic conductivity of unsaturated soils. Soil Sci. Soc. Amer. J. 44: 892-898.

Varble, J.L. and J.L. Chávez. 2011. Performance evaluation and calibration of soil water content and potential sensors for agricultural soils in eastern Colorado. Agr. Water Mgt 101:93-106.

Worley, R.E. 1990. Pecan leaf scorch in response to various combinations of nitrogen and potassium fertilization. HortScience 25:422-423.

Young, R.E. and G.R. Bachman. 1996. Temperature distribution in large, pot-in-pot nursery containers. J. Environ. Hort. 14:170-176.

Zhang, H., J.L. Schroder, J.J. Pittman, J.J. Wang, and M.E. Payton. 2005. Soil salinity using saturated paste and 1:1 soil to water extracts. Soil Sci. Soc. Amer. J. 69:1146-1151.

Zollinger, N., R. Koenig, T. Cerny-Koenig, and R. Kjelgren. 2007. Relative salinity tolerance of intermountain western United States native herbaceous perennials. HortScience 42:529534. 